\title{
THE TENTH AMENDMENT AFTER GARCIA: PROCESS-BASED PROGEDURAL PROTECTIONS
}

\section{Thomas H. OdOM}

\section{INTRODUCTION}

Garcia v. San Antonio Metropolitan Transit Authority is the most recent attempt by the United States Supreme Court to explicitly develop a workable balance between states' interests protected by the tenth amendment ${ }^{2}$ and the power of Congress to regulate interstate commerce under the commerce clause. ${ }^{3}$ This Comment's initial examination of Garcia in the context of earlier caselaw is designed to establish the parameters of the subsequent proposal; it is not preparatory to a discussion of subjects outside the scope of earlier debate. Additional analysis reveals that Garcia neither abandons limitations on congressional exercise of the commerce power nor proposes abstention from judicial review in this area. Garcia merely requires process-oriented ${ }^{4}$ justifications for judicially-imposed safeguards.

Much of the scholarly literature discussing Garcia has responded to this call for process justifications. Process jurisprudence, originating in the Carolene Products footnote, ${ }^{5}$ has been adapted to define and protect the role of states in our federal system. In addition, commentators have made various proposals for specific safeguards of state interests which, consistent with Garcia, are grounded in process concerns. Unfortunately, proposals to erect substantive limits to congressional power seem to ignore Garcia's primary emphasis on procedural protections, and the suggested procedural safeguards lack adequate exposition and means of enforcement.

Building on several of these recommendations, this Comment outlines a proposal for a procedural safeguard of state interests. This proposal is limited to congressional legislation that is based on the commerce power, regulates the states, and represents the initial intrusion

1469 U.S. 528 (1985).

2 "The powers not delegated to the United States by the Constitution, nor prohibited by it to the States, are reserved to the States respectively, or to the people." U.S. Const. amend. X.

3 U.S. ConST. art. I, § 8, cl. 3.

- This term is defined herein. See infra text accompanying note 60. note 66 .

- United States v. Garolene Prods. Co., 304 U.S. 144, 152 n.4 (1938). See infra 
into an area of state law. Legislation that meets these criteria would be required to contain an express statement of the specific degree to which it affects state law. Specific findings and direct action by Congress, as opposed to delegation to administrative agencies, would be mandated. Compliance with these procedures would be ensured through both judicial review and rules of statutory construction. While no substantive restraint would be placed on Congress, the use of express statements would fundamentally change the legislative process and serve as an effective safeguard of state autonomy. ${ }^{B}$

Clear statement requirements exist in many areas of federal law. The Supreme Court is already, albeit haphazardly, employing this safeguard to protect state interests. While procedural safeguards, including the proposed clear statement requirement, are insufficient to guarantee state autonomy absolutely, they represent an effective means of reducing the need for substantive limitations.

Part I of this Comment examines the Garcia decision and its impact on federalism. Part II(A) traces the subsequent development of process-based theory. Part II(B) examines the proposals of other commentators. Part III outlines an original proposal for a procedural safeguard of state autonomy: Part III(A) outlines the conditions under which this safeguard would apply; Part III(B) describes the procedural requirements that would be imposed; Part III(C) depicts the process of judicial enforcement of the safeguard; and Part III(D) analyzes the effectiveness of the procedural requirements. Finally, Part IV presents support for this original proposal.

\section{Garcia and Its Impact on Federalism}

In National League of Cities $v$. Usery, $^{7}$ a five-to-four majority ${ }^{8}$ of the United States Supreme Court articulated a four-part test for determining when federal legislation under the commerce power exceeds the independent limitations imposed by the tenth amendment. ${ }^{\theta}$ In order for a statute to be held unconstitutional, the Court required that: (1) it

- See infra text accompanying notes 95-182.

7426 U.S. 833 (1976), overruled in Garcia, 469 U.S. 528.

8 Justice Rehnquist's opinion was joined by then Chief Justice Burger and Justices Stewart, Powell, and Blackmun; Justice Blackmun also filed a concurring opinion. See National League of Cities, 426 U.S. 833.

- The test was originally expressed in National League of Cities, 426 U.S. at 845, 852-54. Hodel v. Virginia Surface Mining and Reclamation Ass'n, 452 U.S. 264, 28788 \& n.29 (1981), clarified the test by distinguishing the four parts. It is this reformulation that is generally cited for the definition of the test. See, e.g., Garcia, 469 U.S. at 537; EEOC v. Wyoming, 460 U.S. 226, 236-37 (1983); United Transp. Union v. Long Island R.R., 455 U.S. 678, 684 \& n.9. (1982). 
must regulate "the 'States as States," "10 (2) it must "address matters that are indisputably 'attribute[s] of state sovereignty," "11 (3) it must "directly impair [the state's] ability 'to structure integral operations in areas of traditional governmental functions," "12 and (4) "the nature of the federal interest advanced [must not] be such [as to] justif[y] state submission."13

The underlying issue in National League of Cities was the extent to which employees of state and local governments could be subjected to the minimum wage and overtime provisions of the Fair Labor Standards Act (FLSA). ${ }^{14}$ The Court ruled that application of the FLSA to the states would displace the states' "freedom to structure integral operations in areas of traditional governmental functions," and that while within the scope of the commerce power, such regulations are prohibited by the principles of federalism embodied in the tenth amendment. ${ }^{15}$ National League of Cities was considered most significant because, for the first time since $1936,{ }^{16}$ the Supreme Court placed tenth amendment

10 Hodel, 452 U.S. at 287 (citing National League of Cities, 426 U.S. at 845).

11 Id. at 288 (citing National League of Cities, 426 U.S. at 845).

12 Id. (citing National League of Cities, 426 U.S. at 852).

13 Id. at 288 n.29 (citing Fry v. United States, 421 U.S. 542 (1975), reaffirmed in National League of Cities, 426 U.S. at 852-53).

14 See National League of Cities, 426 U.S. at 835-40.

In 1938, Congress enacted the Fair Labor Standards Act (FLSA), Pub. L. No. 75719, 52 Stat. 1060 (codified as amended at 29 U.S.C. \$§ 201-219 (1982 \& Supp. III 1985)), which prohibited wage agreements at hourly rates less than those Congress fixed by law. Existing caselaw suggested that the FLSA exceeded the bounds of congressional power. See Hammer v. Dagenhart, 247 U.S. 251 (1918) (holding that wages of employees engaged in production were not regulable as interstate commerce). In 1941, the Supreme Court upheld the FLSA against direct challenge. See United States v. Darby, 312 U.S. 100 (1941) (explicitly overruling Hammer v. Dagenhart and sustaining the FLSA against challenges based on lack of congressional power and substantive due process limitations); Van Alstyne, The Second Death of Federalism, 83 Mrch. L. Rev.1709, 1709-10 (1985).

In 1966, Congress amended the FLSA to include certain public employees. Pub. L. No. 89-601, § 102(b), 80 Stat. 830, 831 (codified as amended at 29 U.S.C. $\$ 203$ (d) (1982). These amendments were sustained in Maryland v. Wirtz, 392 U.S. 183 (1968). See Van Alstyne, supra, at 1712 n.15.

In 1974, additional amendments extended the FLSA to cover all state employees. Pub. L. No. 93-259, \& 6(a)(1), (5), (6), 88 Stat. 55, 58-60 (codified as amended at 29 U.S.C. $\S 203(d),(s)(5),(x)(1982))$. These amendments extended the Act to regulate directly the internal functions of state governments. See Van Alstyne, supra, at 1712 \& n.15. Challenges to the expanded scope of the FLSA resulted in Supreme Court invalidation of the 1966 amendments as well as the 1974 amendments. See National League of Cities, 426 U.S. at 837-39, 854 (explicitly overruling Maryland v. Wirtz and recognizing limitations on federal commerce power derived from independent sources in the Constitution). See Van Alstyne, supra, at 1712 n.15. 22.

For subsequent development of the FLSA as background to Garcia, see infra note

15 National League of Cities, 426 U.S. at 852.

18 The trend of limiting federal commerce power expressed in Carter v. Carter 
restrictions upon Congress's exercise of its commerce clause power. ${ }^{17}$ Even before Garcia, however, it was clear that National League of Cities was of limited scope. ${ }^{18}$ In Hodel $v$. Virginia Surface Mining and Reclamation Association, ${ }^{19}$ the Court applied the traditional governmental functions analysis of National League of Cities, but upheld the Surface Mining Control and Reclamation Act of $1977^{20}$ because the Act was directed at private coal miners, and thus did not regulate the "States as States."21

At issue in Garcia was the extent to which the San Antonio Metropolitan Transit Authority (SAMTA) could be subjected to the minimum wage and overtime provisions of the FLSA. ${ }^{22}$ The Supreme

Coal Co., 298 U.S. 238 (1936) and Schechter Poultry Corp. v. United States, 295 U.S. 495 (1935) was reversed by United States v. Darby, 312 U.S. 100 (1941).

${ }_{17}$ See Matsumoto, National League of Cities-From Footnote to Holding-State Immunity from Commerce Clause Regulation, 1977 ARIZ. ST. L.J. 35, 37 n.14; Casenote, State Sovereignty Meets the National Political Process, 54 UMKC L. REv. 369, 373 (1986) (discussing National League of Cities in the context of Matsumoto, supra).

In addition, National League of Cities was only the second decision since 1936 relying solely on federalist limitations to strike down an act of Congress based on any constitutional provision. The only other Court-imposed limitation was the invalidation of congressional attempts to set voting qualifications in state and local elections. See Oregon v. Mitchell, 400 U.S. 112 (1970). This limitation was promptly superseded by constitutional amendment. U.S. CoNST. amend. XXVI. Prior to National League of Cities and Mitchell, the last case to limit congressional power on federalism grounds was Carter Coal, 298 U.S. 238. See Van Alstyne, supra note 14, at 1713 n.19.

18 All of the Supreme Court's post-National League of Cities decisions that applied the four-part test upheld the challenged federal legislation. See EEOC v. Wyoming, 460 U.S. 226 (1983); FERC v. Mississippi, 456 U.S. 742 (1982); United Transp. Union v. Long Island R.R., 455 U.S. 678 (1982); Hodel v. Indiana, 452 U.S. 314 (1981); Hodel v. Virginia Surface Mining and Reclamation Ass'n, 452 U.S. 264 (1981); see also Rapaczynski, From Sovereignty to Process: The Jurisprudence of Federalism After Garcia, 1985 SuP. Cr. REv. 341, $341 \mathrm{n} .3$ (observing that none of these decisions were favorable to the state interest involved).

19452 U.S. 264 (1981).

20 Pub. L. No. 95-87, 91 Stat. 445 (current version at 30 U.S.C. $\$ \S 1201-1328$ (1982 \& Supp. III 1985 \& West Supp. 1987)).

21 Hodel, 452 U.S. at 287-88.

22 Garcia, 469 U.S. at 533.

Under National League of Cities, traditional government functions of the states were immune from national regulation and acts like the FLSA simply were inoperative in these areas. See supra note 14. However, the Supreme Court was immediately confronted with the complex problem of defining which state activities were "traditional government functions." In 1985, the Court reviewed the large number of cases on this issue, many of them inconsistent, and decided that such a test was unworkable. See Garcia, 469 U.S. at 538-43. Rather than attempt to clarify or reformulate a distinction that would exempt certain core state functions, the Court overruled National League of Cities. Subsequently, Congress amended the FLSA to mitigate the impact of compliance by state and local governments. See Fair Labor Standards Amendments of 1985, Pub. L. No. 99-150, 99 Stat. 787.

For a more complete history of the FLSA as background to Garcia, see Van Alstyne, supra note 14, at 1709-13. For a discussion of the 1985 FLSA amendments, see Lynch, Garcia v. San Antonio Metropolitan Transit Authority: An Alternate Opinion, 
Court overruled National League of Cities and abandoned its four-part test, ${ }^{23}$ finding that such state interests "are more properly protected by procedural safeguards inherent in the structure of the federal system than by judicially created limitations on federal power."24 Application of the FLSA overtime and wage requirements to SAMTA was held not to impugn state sovereignty nor violate any other constitutional provision. $^{25}$

Garcia articulates the current position of the Supreme Court. An initial analysis of Garcia's limits clarifies the parameters of this Comment's proposal: the proposal operates only within the scope of earlier debate. Thus the discussion of the boundaries of the caselaw should not be read in anticipation of defining a new area outside the earlier discussion.

Although Garcia employs sweeping language, it is limited by its context. Read together with National League of Cities, it is plain that Garcia's rejection of substantive federalist limitations is limited to the

16 Seton Hall L. Rev. 74, 97-99 (1986).

${ }^{23}$ See Garcia, 469 U.S. at 531, 546-47.

${ }^{24} \mathrm{Id}$. at 552.

The Garcia Court does not address the effectiveness of the political process as a protection of state interests. Reliance on the structure of the federal government ignores two problems: (1) "representatives selected by states do not represent the states as government entities ... [in that] [t]he structural interests of the states, in short, are quite separate and distinct from the substantive policy interests of the people of the various states which are reflected in Congress"; and (2) "Congress faces a conflict of interest whenever its legislation presents an assertion of federal power the states argue infringes on their sovereignty." Baird, State Empowerment After Garcia, 18 URB. LAw. 491, 504 (1986). Quite simply, "Garcia's historical interpretation of the states' ability to protect themselves through the political process is plainly wrong." Id. at 505.

As one commentator has observed:

[I]t does seem so implausible to think that American politics will operate per se to constrain Congress within any serious person's view of merely regulating "Commerce .... among the several States" (especially in the absence of the threat of judicial review), as virtually to compel one's skepticism that those who assert this argument can possibly believe it. Unless, then, one wishes to regard the entire set of provisions respecting enumerated powers as mere precatory expressions in the Constitution (and similarly to regard the tenth amendment as though it said, "Such power as Congress elects not to exert may to that extent leave something for state and local governments to do"), it is difficult to take the political science portion of the whole "safeguards" argument as other than a good-hearted joke.

Van Alstyne, supra note 14, at 1724 n.64.

The power of the federal government over commerce is limited to the regulation of commerce "among the several States." The commerce clause may not be read to exclude this limitation. Cf. Marbury v. Madison, 5 U.S. (1 Cranch.) 137, 174 (1803) ("It cannot be presumed that any clause in the constitution is intended to be without effect; and, therefore, such a construction is inadmissible, unless the words require it.").

${ }^{25}$ See Garcia, 469 U.S. at 554. 
definition of the scope of the commerce power. ${ }^{26}$ Subsequent Supreme Court opinions reaffirming limits on congressional power with respect to states' interests ${ }^{27}$ indicate that federalism has not been broadly abandoned. ${ }^{28}$

Furthermore, Garcia applies only to federal statutes that directly regulate the states. ${ }^{29}$ The National League of Cities/Garcia debate concerns regulation of "States as States"; congressional regulation of private parties under the commerce power is entirely beyond its scope. ${ }^{30}$

28 "National League of Cities addressed the question of whether there are judicially enforceable constitutional constraints on Congress' power under the commerce clause to impose requirements on the states." Baird, supra note 24 , at 492 . The constraint imposed by National League of Cities "never was extended beyond the commerce clause context." Id. at 493. "Certain clauses in the Constitution other than the commerce clause ... . grant to Congress very great power to influence the scope and shape of state and local services, and nothing in the [National League of Cities] decision affected those powers." Van Alstyne, supra note 14, at 1713. In addition, "the Constitution itself imposes a number of restrictions on the states as such, and nothing in the [National League of Cities] decision affects the express powers vested in Congress appropriately to enforce those restrictions." Id. at 1715. The Court's decision to overrule National League of Cities in Garcia must be limited to this context as well.

27 See, e.g., Atascadero State Hospital v. Scanlon, 473 U.S. 234 (1985) (eleventh amendment limitation on federal jurisdiction reaffirmed); Baird, supra note 24, at 492 ("Garcia's reversal of National League of Cities hardly demonstrates that the Supreme Court has abdicated its role as a major arbiter and enforcer of federalism principles.").

28 Garcia did not signify abandonment of a federal system of government; for example, limits on national judicial power based on the eleventh amendment, the abstention doctrine, and a narrow interpretation of habeas corpus authority retain their vitality. See Baird, supra note 24, at 496-501.

${ }^{2 \theta}$ The Court explained:

Appellees have not argued that SAMTA is immune from regulation under the FLSA on the ground that it is a local transit system engaged in intrastate commercial activity. In a practical sense, SAMTA's operations might well be characterized as "local." Nonetheless, it has long been settled that Congress' authority under the Commerce Clause extends to intrastate economic activities that affect interstate commerce.

Garcia, 469 U.S. at 537.

so See National League of Cities, 426 U.S. at 854 ("[W]e have reaffirmed today that the States as States stand on a quite different footing from an individual or a corporation when challenging the exercise of Congress' power to regulate commerce."). The principle underlying National League of Cities

was to prevent the federal government from using its commerce clause powers to regulate state governmental functions, as opposed to regulating private local activities within a state. The Court did not doubt that Congressional power under the commerce clause was plenary within its sphere; it acknowledged that Congress could regulate purely local economic activity if such activity affected interstate commerce. Rather, the point of National League of Cities was that the tenth amendment carved out little islands of state immunity from otherwise permissible federal regulation, when the federal regulation touched upon sensitive areas of state sovereignty.

Balkin, Ideology and Counter-Ideology from Lochner to Garcia, 54 UMKC L. REv. 175, 195 (1986) (citations omitted). 
As one commentator noted: "The exception carved out from the federal powers pertained exclusively to the immunity of internal state governmental processes, and nothing in the opinion even remotely implied that the federal government could not reach any private activity." deed, it was only after the FLSA was extended to affect activities "involv[ing] employing legislative staff, providing local fire protection, supervising parks and playgrounds, managing public housing for the poor, etc. as distinct from manufacturing goods for trade through national and international markets"32 that the Supreme Court recognized the need to limit the reach of the federal commerce power. Thus neither National League of Cities nor Garcia had any effect on the parameters of congressional power over individuals; the sole dispute is over federal authority exercised upon the states. ${ }^{33}$

A careful examination of the Garcia text indicates that even in the context of a commerce power-based statute directly regulating the states, the Court has not completely abandoned a role in protecting states' interests. The political process is identified as the "principal,"s4 but not the "sole" protection of those interests. ${ }^{38}$ The Court declares that "the principal and basic limit on the federal commerce power is that inherent in all congressional action-the built-in restraints that our system provides through state participation in federal governmental action." 38 This language implies that when the primary safeguard fails, some additional source of protection will emerge. ${ }^{37}$ Such a protective

31 Rapaczynski, supra note 18 , at 362-63.

32 Van Alstyne, supra note 14 , at 1712 .

ss An example may serve to distinguish federal regulation of individuals who live within the states from direct regulation of the states themselves. Legislation requiring parents of handicapped minors to report recommended medical treatments to a federal agency is a direct regulation of these individuals. In contrast, federal legislation requiring state legislatures to formulate reporting mechanisms, establish state agencies, and allocate state funds to support such a structure, is a direct regulation of the states.

34 "Apart from the limitation on federal authority inherent in the delegated nature of Congress' Article I powers, the principal means chosen by the Framers to ensure the role of the States in the federal system lies in the structure of the Federal Government itself." Garcia, 469 U.S. at 550 (emphasis added). "In short, the Framers chose to rely on a federal system in which special restraints on federal power over the States inhered principally in the workings of the National Government itself, rather than in discrete limitations on the objects of federal authority." Id. at 552 (emphasis added).

ss Commentators have not failed to observe the potential significance of this choice of language. See, e.g., Van Alstyne, supra note 14, at 1720 n.52 ("Justice Blackmun writes of political process safeguards as the 'principal' (rather than as the sole) limitation upon Congress.").

${ }^{36}$ Garcia, 469 U.S. at 556 (emphasis added).

87 Indeed, Garcia stated that, because the safeguards of the political process had not malfunctioned in enacting the FLSA amendments, the Court was not required "to identify or define what affirmative limits the constitutional structure might impose on federal action affecting the States under the Commerce Clause." Garcia, 469 U.S. at 


\section{role has traditionally been played by the Supreme Court as the final}

556 (citing Coyle v. Smith, 221 U.S. 559 (1911)). Coyle held that Congress could not require a territory to move its capital as a condition of admission to statehood. Cited in this context, Coyle implies that a similar congressional command based on the commerce power would be unconstitutional. But given the practically unlimited reach of the commerce power, see Katzenbach v. McClung, 379 U.S. 294, 304-05 (1964), a constitutionally-based substantive protection of federalism would be required to find this command invalid because even the strictest procedural requirements could, in theory, be satisfied and still allow such an order.

One scholar notes that "the rationale of Garcia would [irrespective of Coyle] be ample to sustain acts of Congress well drawn to 'persuade' states to move their state capitols [sic] to their principal centers of commerce." Van Alstyne, supra note 14, at 1720 n.52. Thus it must be that certain areas of core state functions are protected from federal interference; any procedural safeguard which would theoretically allow full compliance and still produce an invalid command must be supplemented by substantive protections.

The problem with this substantive protection is defining what core functions are protected. Commentators suggest several areas:

Congress may not pass and the executive may not implement legislation affecting the means of selection of members of either of those branches of government, for our Constitution spells out that their selection is apportioned along state lines and may not be changed without state consent; Congress and the executive may not tax certain functions of the states; nor may the federal government make or enforce laws determining the location of the state capital.

Baird, supra note 24, at 498 (citations omitted). Professor Rapaczynski likewise lists certain internal state functions with which the federal government could not interfere:

First, there are some state governmental functions so directly related to the federalist concern with preventing tyranny that they present rather easy cases for judicial intervention . . . [F]or example, federal interference with the agenda of the highest state legislative and executive organs is likely to undermine the overall autonomy of the political processes in the states and eliminate their constitutional role within the federal system. Similarly, an interference with the state electoral processes, insofar as it is not clearly related to the protection of individual rights but threatens to gerrymander the local districts in order to change the configuration of political forces in favor of the nationally powerful interests, would be clearly beyond the pale. A gradual subordination of state police forces to a federal command structure would cripple the states' ability to enforce their basic choices and resist tyrannical pressures from above. A radical limitation of the states' ability to tax would make their fiscal solvency a matter of federal grace and ultimately make a mockery of the federalist concerns.

It may be a little harder to come up with equally clearly unconstitutional instances of federal interference with the states' function of enhancing participation . . . [but examples exist. For instance,] given the special participatory mode in which school boards operate in most states, a federal education law that would attempt to transform those boards into an extension of the federal bureaucratic machinery would strike at the very core of participatory politics in the United States.

Rapaczynski, supra note 18 , at $415-16$ (citations omitted). What is needed is a theory to classify these areas. National League of Cities provided an exception for internal processes that was not addressed in the subsequent decisions. See id. at 363 . This definition of internal decision-making functions is similar to Professor Rapaczynski's first set of protected areas.

Rather than define functions which are essentially internal or related to a state's 
arbiter of the Constitution. ${ }^{38}$

Garcia recognizes the need for a continued Court role as a secondary protector of the states. Rather than abdicating this function, the Court states only that the justification for judicially imposed limitations on congressional action under the commerce power must be processorientated rather than substantive. The Court declared that:

[W]e are convinced that the fundamental limitation that the constitutional scheme imposes on the Commerce Clause to protect the "States as States" is one of process rather than one of result. Any substantive restraint on the exercise of Commerce Clause powers must find its justification in the procedural nature of this basic limitation, and it must be tailored to compensate for possible failings in the national political process rather than to dictate a "sacred province of state autonomy."38

Accordingly, Garcia does not actually require a shift from substantive protection of state interests to procedural limitations on federal power:

[W] hile the justification of the 'restraint on the exercise of Commerce Clause powers' must be one of 'process,' the restraint itself may be 'substantive,' that is, need not be limited to assuring the proper amount of state influence on the federal level but may instead address itself directly to the problem of national overreaching. ${ }^{40}$

Garcia hence serves as the stimulus for the development of procedural justifications for the protection of federalism. After changing

decision-making ability, other commentators have suggested a division between "distribution" and "source" issues. See Baird, supra note 24, at 508-11.

Once these areas are identified, the challenge of generating an appropriate protection still remains. For instance, a prohibition of direct coercion could be circumvented under the spending power unless there was a bar to the use of conditions in these areas. Thus both Baird and Rapaczynski supplement their substantive safeguards with limitations on the spending power. See Baird, supra note 24, at 511 n.93; Rapaczynski, supra note 18, at 417-18; infra note 150 .

38 See Marbury v. Madison, 5 U.S. (1 Cranch) 137, 177-78 (1803) ("It is emphatically the province and duty of the judicial department to say what the law is. . . . This is the very essence of judicial duty."); see also Garcia, 469 U.S. at 567 (Powell, J., dissenting) ("At least since Marbury v. Madison, it has been the settled province of the federal judiciary to 'say what the law is' with respect to the constitutionality of Acts of Congress.") (citation omitted).

${ }_{39}$ Garcia, 469 U.S. at 554 (emphasis added) (citing EEOC v. Wyoming, 460 U.S. 226, 236 (1983); see also Rapaczynski, supra note 18, at 364 (discussing Garcia's formulation of "an approach to the elaboration of the judicial standards of review").

to Rapaczynski, supra note 18 , at 364 . 
course four times in this century, ${ }^{\mathbf{4 1}}$ most recently reversing itself within a period of nine years, ${ }^{\mathbf{2}}$ the Court has initiated a search for a more durable theory of tenth amendment limitations on federal power. ${ }^{\text {s }}$ Several commentators have characterized Garcia as the foundation of "a more persuasive and lasting constitutional basis for protecting state[s]" than was to be found under National League of Cities. ${ }^{44}$

Seen in this light, Garcia is significant for two reasons. First, it rejects National League of Cities as unworkable. Second, and more importantly, it calls for the development of new theories of federalismbased limitations on the commerce power. ${ }^{45}$

While the case was criticized on several grounds, ${ }^{46}$ the Supreme Court's "basic justification for overruling National League of Cities was the incoherence and arbitrariness of the 'integral state functions'

41 The first ruling on the issue was Hammer v. Dagenhart, 247 U.S. 251 (1918). The second interpretation was expressed in United States v. Darby, 312 U.S. 100 (1941) (overruling Hammer v. Dagenhart) and Maryland v. Wirtz, 392 U.S. 183 (1968). The third posture is found in National League of Cities 426 U.S. 833 (overruling Maryland v. Wirtz). The fourth and most recent position is represented by Garcia, 469 U.S. 528 (reversing National League of Cities). For a fuller explanation, see supra notes $14 \& 22$ and accompanying text.

12 See supra note 41.

43 But cf. Garcia, 469 U.S. at 580 (Rehnquist, J., dissenting) ("I do not think it incumbent on those of us in dissent to spell out further the fine points of a principle that will, I am confident, in time again command the support of a majority of this Court.").

" Baird, supra note 24, at 492; see also id. at 515 ("Garcia may present an opportunity for the states to institutionalize greater political clout in Congress."); Rapaczynski, supra note 18, at 359-60 ("[T] She Supreme Court's decision in Garcia ... should be viewed as the last logical step in a long evolution of the sovereigntybased jurisprudence of federalism. ... [I]ts main thrust is to reject the usefulness of sovereignty-based analysis and to replace it with a focus on the nature of the political process responsible for making federalism-related decisions."); Balkin, supra note 30, at 214 ("The Court is now left with the task of developing a theory which explains when and how courts will protect state and local interests where the national political process fails to do so.").

45 See Rapaczynski, supra note 18, at 341-42 ("Garcia's importance lies, above all, in revealing the absence of anything approaching a well elaborated theory of federalism that would provide a solid intellectual framework for an articulation of the Justices' divergent views on state-national relations.").

'B Commentators analyzing Justice Brennan's dissent in National League of Cities have identified five separate grounds of criticism:

"(1) that Congress is responsible for determining the federal-state balance of power under the commerce clause; (2) Congress' regulatory powers under the commerce clause are plenary and not limited by state sovereignty; (3) Justice Rehnquist's [majority] opinion ignored the Court's post-1937 precedents; (4) National League of Cities merely substitutes the Court's policy judgement for that of Congress; (5) the traditional governmental functions test is unworkable."

Casenote, supra note 17, at 373 n.43, citing Matsumoto, supra note 17, at 63 n.144. 
test." 17 After reviewing the application of the traditional governmental functions test by lower courts, the Garcia majority stated: "We find it difficult, if not impossible, to identify an organizing principle that places each of the cases in the first group on one side of a line and each of the cases in the second group on the other side." 48 The Court concluded that "the attempt to draw the boundaries of state regulatory immunity in terms of 'traditional governmental function[s]' is . . . unworkable." Ulimately, although Garcia suggested several grounds for overruling National League of Cities, ${ }^{\text {so }}$ the test failed primarily because of this perception. ${ }^{\text {si }}$

The Court observed: "What has proved problematic is not the perception that the Constitution's federal structure imposes limitations on the Commerce Glause, but rather the nature and content of those limitations. . . . The states unquestionably do 'retai[n] a significant measure of sovereign authority." "\$2 Scholarly commentators have not hesitated to accept this invitation to fashion a new, more workable jurisprudence. $^{\mathrm{s}}$

\section{Post-Garcia Developments}

\section{A. Process-Based Theory}

The scholarly response to Garcia's invitation to develop a new jurisprudence of federalism has been largely limited by the parameters of the National League of Cities/Garcia debate. Proposals address only the area bounded by the tenth amendment and the commerce power; accordingly, these statements are limited to congressional exercise of the commerce power ${ }^{54}$ that directly regulates the states. ${ }^{\mathrm{S5}}$

Several scholars attempt to reformulate National League of Cities or to develop similar sovereignty-based substantive safeguards. For in-

47 Balkin, supra note 30 , at 210 .

48 Garcia, 469 U.S. at 539.

19 Id., 469 U.S. at 531.

so See supra note 46 for the several grounds for criticism.

s1 See Baird, supra note 24, at 507 ("The Court, in my judgement, overruled National League of Cities because it found the legal test set down in that case unworkable and incoherent, not because it found federalism irrelevant to our time."); Mahoney, Justice Blackmun, Congress and the States: From National League of Cities to Garcia, 54 UMKC L. REv. 215, 239 (1986).

52 Garcia, 469 U.S. at 547, 549 (quoting EEOC v. Wyoming, 460 U.S. 226, 269 (1983) (Powell, J., dissenting)).

ss See, e.g., Baird, supra note 24, at 514-17; Rapaczynski, supra note 18, at 414-

19. For a discussion of these proposals, see infra notes 77-80 and 91-94.

See supra notes $26-28$ and accompanying text.

ss See supra notes $29-33$ and accompanying text. 
stance, Professor Lynch would revive National League of Cities but with the proviso 'that its 'traditional governmental function' test be abandoned in favor of a broader balancing of the competing local and Federal interests involved both in that case and in future cases." Under this balancing test, Lynch concludes that both National League of Cities and Garcia were properly decided due to the difference in the intensity of the federal interest. ${ }^{67}$

Nonetheless, while Garcia arguably envisions some measure of substantive protection, ${ }^{\mathbf{5 8}}$ the opinion emphasizes procedural justifications and safeguards. ${ }^{59}$ It is in this arena that the resulting scholarship has been most innovative.

Professor Rapaczynski describes the purpose of process-oriented jurisprudence as

aim[ing] . . . at an elaboration of judicial standards, the justification of which does not rely on the desirability of specific substantive results but rests instead on the identification of some defects in the political process that prevent it from operating in accordance with the function assigned to it in the

${ }^{86}$ Lynch, supra note 22, at 76 (citation omitted). But see Balkin, supra note 30 , at 209 ("A balancing approach is inimical to a conceptualist jurisprudence, which does not see rights in conflict which need to be balanced but rather sees carefully demarced and mutually exclusive spheres of individual rights (or in this case, of state and federal sovereignty).").

${ }^{57}$ See Lynch, supra note 22 , at 76 . He notes that "the abiding Federal interest, not present in National League of Cities, [was] that under the [Urban Mass Transportation Act of 1964] the Federal Government provided substantial revenue toward the cost of the transit system's operation as well as toward its capital and technical assistance cost." Id. at 93.

${ }^{88}$ See supra note 40 and accompanying text.

59 See supra notes 34-39 and accompanying text. Several commentators have challenged the notion that any valid distinction exists between "substance" and "procedure." Carolene Products jurisprudence and the theories of John Hart Ely, see J. ELY, Democracy and Distrust, A Theory of Judicial Review (1980), are favorite targets for criticism on this ground. See, e.g., Tribe, The Puzzling Persistence of Process-Based Constiutional Theories, 89 YALE L.J. 1063 (1980); Berger, Ely's "Theory of Judicial Review," 42 OHiо St. L. Rev. 87 (1981); Perry, The Principle of Equal Protection, 32 Hastings L.J. 1133, 1142-45 (1981); Ackerman, Beyond Carolene Products, 98 HaRv. L. REv. 713, 734-37 (1985). Even so, it must be noted that: (1) the Supreme Court continues to perceive a distinction between substantive and procedural protections, and (2) the proposed safeguard outlined herein is undoubtedly more process-based than most of the doctrines founded on Carolene Products. If the "safeguards" and not merely the "justifications" are procedural, no outcome is forbidden. Under equal protection doctrine founded on Carolene Products, a race conscious statute that explicitly burdens fundamental rights will be struck down regardless of the formalities of enactment. If one understands Garcia to require procedural protection then statutes explicitly directed at state autonomy would be upheld if they were adopted with the requisite formalities. 
Constitution. ${ }^{60}$

Such an approach requires both an examination of the role of the states in our constitutional system and the creation of specific safequards to protect that role. ${ }^{61}$

${ }^{\circ 0}$ Rapaczynski, supra note 18, at 365; see also Fullilove v. Klutznick, 448 U.S. 448, 549 n.24 (1980) (Stevens, J., dissenting) ("[T]he last few years have reawakened our appreciation of the primacy of process over product in a free society, the knowledge that no ends can be better than the means of their achievement." (quoting Linde, Due Process of Lawmaking, 55 NeB. L. REv. 197, 255 (1976))).

61 Federalism may be analyzed in terms of efficiency, equity, and liberty. Most cconomists agree that some goods and services may be more efficiently administered on a smaller scale than that of the whole nation. For example, Wallace E. Oates observes that:

[A] decentralized public sector possesses several economically desirable characteristics. First, it provides a means by which the levels of consumption of some public goods can be tailored to the preferences of subsets of the society. In this way, economic efficiency is enhanced by providing an allocation of resources that is more responsive to the tastes of consumers. Second, by promoting increased innovation over time and by providing competitive pressures to induce local governments to adopt the most efficient techniques of production, decentralization may increase both static and dynamic efficiency in the production of public goods. Third, a system of local government may provide an institutional setting that promotes better public decision-making by compelling a more explicit recognition of the costs of public programs.

W. OAtes, Fiscal Federalism 13 (1972). Given these advantages to decentralization, Oates concludes that the optimal form of government is a federal system in which

[e]ach level of government, rather than attempting to perform all the functions of the public sector, does what it can do best. The central government presumably accepts primary responsibility for stabilizing the economy, for achieving the most equitable distribution of income, and for providing certain public goods that influence significantly the welfare of all members of society. Complementing these operations, subcentral governments can supply those public goods and services that are of primary interest only to the residents of their respective jurisdictions.

Id. at 14 (citing the agreement of economists Richard Musgrave and Dick Netzer about the optimality of this distribution of governmental tasks).

Economic efficiency arguments for federalism, however, do not address the issue of whether the units which provide goods and services are autonomous entities or merely administrative subdivisions of a centralized government. For economists, "decentralization of the public sector is of importance primarily because it provides a mechanism through which the levels of provision of certain public goods and services can be fashioned according to the preference of geographical subsets of the population." Id. at 17. Thus, Oates distinguishes the economic definition of federalism from the political science definition: "[I]t makes little difference to the economist whether or not decisionmaking at a particular level of government is based on delegated or constitutionally guaranteed authority." Id. Efficiency considerations, then, do not favor states over regions, districts, or sections. But see infra note 64 .

Equity considerations also tend to disfavor federalism. The easiest way to ensure that everyone receives equal entitlements is to have all entitlements centrally administered. However, this ignores the fact that local variations in conditions may call for different entitlements altogether. Yet even if local conditions do justify different levels of entitlement, this does not require autonomous administration. Again, administrative 
Liberty concerns seem, both now and in 1787 , to provide the most rational reasons for the establishment of a federal system of government. $^{62}$ Federalism, like the separation of powers among the branches of the national government, serves "as yet another check on the concentration of power in general, for the sake of protecting certain forms of life or preventing arbitrary and tyrannical imposition by some interests upon others." ${ }^{\text {"Bs }}$ States' liberty-enhancing functions are two-fold: (1) by preventing the complete concentration of power in one governmental body, a safeguard against overreaching by that body is established, and (2) by allowing for decentralized decision-making, local majorities may retain some power rather than being fated to become a national minority in all respects. ${ }^{64}$

For our federal system to serve its dual roles of protecting against tyranny by the national government and allowing for decentralized control by local majorities, the states' decision-making process must remain autonomous. When the central government can interfere with the inter-

subdivisions may serve as well as states. But see infra note 64.

62 James Madison observed that:

In a single republic, all the power surrendered by the people is submitted to the administration of a single government; and the usurpations are guarded against by a division of the government into distinct and separate departments. In the compound republic of America, the power surrendered by the people is first divided between two distinct governments, and then the portion alloted to each subdivided among distinct and separate departments. Hence a double security arises to the rights of the people. The different governments will control each other, at the same time that each will be controlled by itself.

The Federalist No. 51, at 323 (J. Madison) (C. Rossiter ed. 1961)(emphasis added).

Decentralized political institutions also enhance the public education of the citizens by fostering widespread direct participation in the political process. See J.S. Mill, Representative Government, in THE TRAdITION of FREEDOM 547, 552-53 (M. Mayer ed. 1957) (the government that most successfully fosters the virtue and intelligence of the people has "every likelihood of being the best in all other respects"). The same level of participation would be difficult to replicate in a system that merely delegated certain administrative decisions to subdivisions. $C$ f. San Antonio Indep. School Dist. v. Rodriguez, 411 U.S. 1, 49-53 (1973) (Justice Powell's majority opinion defends the financing of public school districts from local funds to preserve the independence of the districts and to enhance participation in governance of the district). The civic education and participation purpose reinforces the liberty-enhancing function of federalism: a more informed and active public is less likely to acquiesce in tyranny.

Bs Rapaczynski, supra note 18 , at 362 .

Once justified on a liberty-enhancing basis, federalism may receive additional support on efficiency and equity grounds. That is, given the existence of states as decentralized administrators, it may be more efficient to use that structure rather than creating an additional system of subdivisions of the central government. Furthermore, if variations in some entitlements exist due to the differing views of local majorities, the equity goal of setting levels of entitlement to meet local needs, rather than a uniform standard, will prevail. Nevertheless, it is the liberty-enhancing function of federalism that serves as its basic justification. 
nal operations of state government, the state government cannot fulfill its purposes. This is reflected in concerns about federal legislation that directly regulates the states. ${ }^{65}$ Absent an explicit substantive protection from regulation of the "States as States," procedural protections must be formulated to preserve the role of the states in the federal system. Garcia initiates the search for such process-based limitations.

Several commentators analogize Garcia to the Carolene Products footnote ${ }^{\mathbf{B}}$ as a catalyst to the establishment of process-based justifications for the protection of certain interests. ${ }^{67}$ In both cases, the Supreme Court upheld federal legislation while announcing that higher standards of judicial review would be employed in cases where political safeguards had failed. After Carolene Products, the Court, with support from commentators, searched for standards to define the classes of cases in which procedural safeguards would be required. ${ }^{68}$

One such protection rooted in the Carolene Products footnote is a high level of judicial scrutiny of legislation directed at racial minorities. $^{6 \theta}$ This procedural protection serves to ensure that a majority does

6s See supra notes $29-33$ and accompanying text.

os United States v. Garolene Prods. Co., 304 U.S. 144, 152-53 n.4 (1938). That footnote states:

There may be narrower scope for operation of the presumption of constitutionality when legislation appears on its face to be within a specific prohibition of the Constitution, such as those of the first ten amendments, which are deemed equally specific when held to be embraced within the Fourteenth.

It is unnecessary to consider now whether legislation which restricts those political processes which can ordinarily be expected to bring about repeal of undesirable legislation, is to be subjected to more exacting judicial scrutiny under the general prohibitions of the Fourteenth Amendment than are most other types of legislation. On restrictions on the right to vote; on restraints upon the dissemination of information; on interference with political organizations; [and] prohibition of peaceable assembly [precedents for hightened scrutiny exist].

Nor need we enquire whether similar considerations enter into the review of statutes directed at particular religious, or national, or racial minorities: whether prejudice against discrete and insular minorities may be a special condition, which tends seriously to curtail the operation of those political processes ordinarily to be relied upon to protect minorities, and which may call for a correspondingly more searching judicial inquiry.

Id. (citations omitted).

o7 See Rapaczynski, supra note 18, at 364-65; Balkin, supra note 30, at 211.

os The Supreme Court had not developed a theory for the protection of "discrete and insular minorities" at the time of the footnote. See Cover, The Origins of Judicial Activism in the Protection of Minorities, 91 YaLE L.J. 1287, 1294-95 (1982). Subsequent clarification was required to establish the scope of protection now attributed to the footnote. For example, the first "explicit reference to race as a 'suspect' criterion did not come until . . . Korematsu v. United States, 323 U.S. 214 (1944)." G. GuNTHER, Cases and Materials on Constitutional Law 624 (11th ed. 1985).

6o Legislation directed against racial minorities is explicitly mentioned in the foot- 
not consciously use its power to disenfranchise minorities and undermine the democratic process. Procedural safeguards do not deny congressional powers, but rather insist that

the exercise of these broad powers is subject to the constraints imposed by the Due Process Clause of the Fifth Amendment.

.. .For just as procedural safeguards are necessary to guarantee impartial decisionmaking in the judicial process, so can they play a vital part in preserving the impartial character of the legislative process. $^{70}$

In addition to ensuring that a majority does not consciously use its power to disenfranchise minorities and thus undermine the democratic process, express consideration of the impact of legislation ensures that the legislature has not inadvertently done the same. Thus, in Fullilove v. Klutznick ${ }^{\text {71 }}$ Justice Stevens criticized race-conscious legislation where " $[t]$ here is not one word in the remainder of the Act or in the legislative history that explains why any Congressman or Senator favored this particular [provision]." ${ }^{.72}$ In the context of race-conscious

note. See supra note 66 . The Carolene Products footnote may be seen as establishing four more general bases for a stricter standard of judicial review: (1) facial inconsistency with an express constitutional prohibition (first paragraph); (2) "legislation which restricts . . . political processes" (second paragraph); (3) infringement of fundamental rights (derived from the rights enumerated in the second paragraph); (4) discrimination against "discrete and insular minorities" or suspect classes (third paragraph). See Cover, supra note 68, at 1290-97.

7o Fullilove v. Klutznick, 448 U.S. 448, 548-49 (1980) (Stevens, J., dissenting). Justice Stevens' formulation of this concept has, on occasion, been embraced by a majority of the Supreme Court. See Hampton v. Mow Sun Wong, 426 U.S. 88 (1976). In Mow Sun Wong, the Court stated that particularly where an administrative agency is involved, the due process clause of the fifth amendment may limit the government's authority to act. $I d$. at 103 . The case involved the review of "an exercise of the plenary federal power over immigration and naturalization," $i d$. at 99 , over which "the authority to control . . . is not only vested solely in the Federal Government, rather than the States, but also .... is of a political character and therefore subject to only narrow judicial review." Id. at 101-02 n.21.

Most recently, Justice Powell advocated an inquiry into "the legislative process" in Davis v. Bandemere, 106 S. Ct. 2797, 2832 (1986) (Powell, J., concurring in part and dissenting in part). He expressly refers to the passage of "bills with no substantive content" for the purpose of legislating by conference committee; the exclusion of the minority party from voting membership on the conference committee; the absence of public hearings; the presentation of legislation "[t]wo days before the end of the General Assembly's regular session" resulting in only forty hours for the opposition to prepare an alternative proposal; adoption by "party line vote"; and "substantial evidence that [the majority party] w[as] motivated solely by partisan considerations." See id. at 2833-34.

71448 U.S. 448 (1980).

72 Fullilove, 448 U.S. at 535 (Stevens, J., dissenting); see also Mow Sun Wong, 426 U.S. at 115 ("There is nothing in the record before us, or in matter of which we 
statutes he has stated that "[u]nless Congress clearly articulates the need and basis for a racial classification, and also tailors the classification to its justification, the Court should not uphold this kind of statute."

As an example of the level of congressional attention required in areas of process concern, Stevens cites the "enactment of the Voting Rights Act [which] was preceded by exhaustive hearings and debates concerning discriminatory denial of access to the electoral process, and [which] became effective in specific States only after specific findings were made."74 This conscious excercise of congressional power is contrasted with the "perfunctory consideration of an unprecedented policy decision of profound consitutional importance to the Nation ... [which indicates] that a busy Congress has acted precipitately."'75

For these reasons, Justice Stevens argues that

judicial review should include a consideration of the procedural character of the decision-making process. A holding that the [legislation] was not adequately preceded by a consideration of less drastic alternatives or adequately explained by a statement of legislative purpose would be far less intrusive than a final determination that the substance of the decision is not "narrowly tailored to the achievement of that goal. ${ }^{76}$

Because procedural limitations on congressional power are less burdensome, they may be substituted for substantive restraints where the Supreme Court would have difficulty expressing the appropriate boundaries of a substantive restraint.

\section{B. Proposals for Protection of State Interests}

Building on process-based theory, scholars have proposed a number of mechanisms to protect states' interests. In general, these mechanisms either attempt to change institutions or establish new procedures. Proposed institutional changes include a reshaping of the role of Con-

may properly take judicial notice, to indicate that the Commission actually made any considered evaluation of the relative desirability of [alternatives to the challenged provision]." (emphasis added)).

${ }^{73}$ Fullilove, 448 U.S. at 545 (Stevens, J., dissenting).

74 Id. at 546 .

75 Id. at 550; of. Mow Sun Wong, 426 U.S. at 110 (Justice Stevens similarly acknowledges inertia in the executive branch by distinguishing "between acceptance by the President of a Commission rule to which no objection has been made and a decision made by the President himself.").

${ }^{76}$ Fullilove, 448 U.S. at 551. 
gress. As one commentator has observed, "[i]f Congress is to assume the guardianship of the interests of state and local governments . . . then congress must set up institutional structures that ensure that the states' interests are protected."77

Specifically, Congress could "establish a committee on state and local government in each house." diction over "all bills affecting state and local governments." committee would be charged with ensuring that "the states' perspective be fully considered" and with drafting legislation that minimized inadvertent intrusion on state government. ${ }^{80}$ This would serve as a safeguard of the states' interests to the extent that the committee (1) "would provide a focal point for overall assessment of the extent to which Congress has taken authority unto itself or of the extent to which it has deferred to state assertion of authority," and (2) it would provide "the states [with] a forum in which to develop sensitivity to their role as separate sources of authority."

This proposal has several inherent limitations. The creation of such a committee would not change the fact that the members of the committee do not represent the interests of the states as distinct from the concerns of the residents of those states, ${ }^{82}$ nor does this proposal address the conflict of interest of a congressional committee entrusted with limiting the expansion of federal power. ${ }^{83}$ In addition, this is merely another form of reliance on congressional self-control. No independent authority may be invoked to resolve claims that Congress failed to assign a pending bill to this committee, that the committee failed to fully represent the states' interests, or that Congress disregarded the

77 Baird, supra note 24, at 514.

78 Id.

79 Id. This committee "ideally should have joint jurisdiction over all bills affecting state and local governments. Such jurisdiction should encompass legislation directly involving state and local governments (such as the FLSA or funding programs) and that may indirectly affect their ability to govern." Id. at 514-15.

8o Id. at 515 . The committee would

insist that the states' perspective be fully considered when they may be included in the coverage of a law. It also would help shape the form of a broad range of legislation. For example, the degree of clarity in the drafting of a statute will affect whether it is interpreted by the federal courts as preempting regulation in a field, or whether conditions are imposed on federal grants to states, or whether Congress intended to rely on section 5 of the fourteenth amendment. A congressional committee such as that proposed can monitor the drafting of legislation and legislative history with knowledge of trends in judicial interpretation in these areas.

Id.
81 Id.
82 See supra notes 24, 33.
ss See supra note 24 . 
recommendations of the committee. In short, the establishment of a congressional committee on state and local government would not adequately protect the states in the national political process.

Another approach designed to increase national government accountability for expansion into areas of state interest would require that such decisions be made by a "political" branch of government. This would check the congressional practice of delegating authority to administrative agencies. Congress would be prohibited from "delegat[ing] to agency officials legislative determinations that affect state sovereign interests," because "[a]gency officials are removed from the 'national political process' that [Garcia] identified as the necessary check on federal overreaching." ing deference to administrative agencies in federalism areas: (1) deference involves a broad, and perhaps unconstitutional, delegation of legislative powers to the executive branch, thus weakening the separation of powers, ${ }^{88}$ and (2) the agency is further removed from the political process that serves as the primary safeguard of states' interests. ${ }^{87}$

34 Baird, supra note 24, at 516 .

as Id. at 516-17, (citing Garcia, 469 U.S. at 575-77 (Powell, J., dissenting)). The author of this proposal observes that it is an open question

whether federal regulations not expressly required by statute may override conflicting state law that implicates sovereign state interests. I have thought for some time that Congress is ripe for a challenge that it has exceeded its authority to delegate by giving the executive branch legislative functions. This doctrine may support a powerful argument that Congress certainly may not delegate to agency officials legislative determinations that affect state sovereign interests.

Id. at 516-17.

so There have been several recent attempts to revive the non-delegation doctrine. See, e.g., American Textile Mfrs. Inst. v. Donovan, 452 U.S. 490, 543-48 (1981) (Rehnquist, J., dissenting); Industrial Union Dep't, v. American Petroleum Inst., 448 U.S. 607, 671-85 (1980) (Rehnquist, J., concurring), see also Bowsher v. Synar, $106 \mathrm{~S}$. C.. 3181, 3185, 3193 n.10 (1986) (majority opinion raised, but did not resolve, the issue of the nondelegation doctrine).

The aforementioned proposal, however, does not call for a complete revival of the nondelegation doctrine. Stricter guidelines would be required only when the agency was engaged in regulation "that affect[s] state sovereign interests." Baird, supra note 24 , at 516.

87 The degree of agency accountability is subject to debate. At least one commentator has maintained that agencies are more responsive to the public than Congress. See Mashaw, Prodelegation: Why Administrators Should Make Political Decisions, $1 \mathrm{~J}$. LAW, ECON. \& ORGANIzATION 81, 95-99 (1985) (arguing that agencies are accountable directly to the President, who has a larger constituency than individual congressmen). Others have maintained that decisions made outside of Congress are inherently less representative of the views of the electorate. Ely states that delegation of basic political decisions "is undemocratic, in the quite obvious sense that by refusing to legislate, our legislators are escaping the sort of accountability that is crucial to the intelligible functioning of a democratic republic." J. ELY, supra note 59, at 132. Even justices who currently oppose the revival of the nondelegation doctrine may not accept the no- 
This safeguard is an important element of any proposal to prevent federal power from undermining state authority. Standing alone, however, a limit on agency power is not enough; it creates no additional barrier to legislation that consciously ${ }^{88}$ or inadvertently ${ }^{89}$ intrudes upon the autonomy of the states.

Other proposals attempt to impose procedural requirements rather than change institutional structures. One such proposal is to require a clear statement of congressional intent prior to preemption of a field of state law:

It will be important to move the courts to require specific statutory language before congressional enactments will be held to preempt a regulatory field. The spending clause cases provide a useful analogy. The Court has invoked the federalism interests of the states to require express statement by Congress of conditions on grants so that the states can either accept the money and the conditions that come with it, or reject them both. The states' federalism interests also should support the requirement that Congress expressly state its intention to preempt a specific field before legislation will be assumed to do so. ${ }^{.0}$

The clear statement approach has, in fact, been endorsed as particularly suited to.Garcia's requirements. Professor Rapaczynski opines:

[I]t is always open for the courts to assume a more deferential posture to legislative assessments but to try to assure at the same time that the legislators themselves pay more attention to the factors that judges view as constitutionally important. This has been done in fact by the Court in some areas of Commerce Clause adjudication where judicial deference to a Congressional determination that a given activity concerned interstate commerce was conditioned on the Congress's explicit statement to this effect or a requirement of a series of specific findings. This kind of technique, particularly suited to Garcia's confidence in political accountability,

tion that agencies are as accountable as Congress. See, e.g., United States v. Robel, 389 U.S. 258, 276 (1967) (Brennan, J., concurring) ("Formulation of policy is a legislature's primary responsibility, entrusted to it by the electorate, and to the extent Congress delegates authority under indefinite standards, this policy-making function is passed on to other agencies, often not answerable or responsive in the same degree to the people." (emphasis added)).

${ }_{88}$ See supra note 70 and accompanying text.

so See supra notes 71-75 and accompanying text.

90 Baird, supra note 24 , at 516. 
deserves more sustained consideration. ${ }^{91}$

Rapaczynski would impose the procedural requirement of (1) an explicit statement by Congress, or (2) a "series of specific findings" when federal legislation affects state interests. ${ }^{82}$ Rapaczynski does not address two problems inherent in this formulation. First, "explicit congressional statements" may, in fact, be neither explicit nor statements by Congress; statements from the subcommittee reports of a past Congress may suffice. ${ }^{93}$ Second, no enforcement mechanism is proposed to ensure compliance with the mandated procedure. Without judicial review, the "series of specific findings" may be based on clearly erroneous facts.

Taken together, a requirement that only Congress, rather than administrative agencies, may "override conflicting state law that implicates sovereign state interests," quirement of a clear statement or specific findings by Congress may form an effective, process-based protection of state autonomy.

-1 Rapaczynski, supra note 18, at 418-19 (footnote omitted).

22 Professor Rapaczynski would impose substantive limits on Congress in addition to these procedural safeguards. Congress would be prohibited from interfering with the legislative and executive agenda of the state, as well as with a state's electoral process, to the extent that the interference is not related to the protection of individual rights. See id. at 414-19.

93 A challenge to the "minority set-aside" provision of the Public Works Employment Act of 1977 turned on the issue of whether Congress had made a finding of past discrimination in the construction industry. The provision was upheld even though the 1977 congressional debates contained no explicit reference to any past discrimination in the industry. A 1977 House Committee evaluation of the program was located, which in turn referred to a 1975 House Subcommittee evaluation that contained a single reference to past industry discrimination. See Fullilove, 448 U.S. at 465 . In his concurrence, Justice Powell stated:

[Petitioners] assert[] that a reviewing court may not look beyond the legislative history of the [Act] itself for evidence that Congress believed it was combatting invidious discrimination. But petitioners' theory would erect an artificial barrier to full understanding of the legislative process. . . .

.. . The creation of national rules for the governance of our society simply does not entail the same concept of recordmaking that is appropriate to a judicial or administrative proceeding. Congress has no responsibility to confine its vision to the facts and evidence adduced by particular parties. Instead, its special attribute as a legislative body lies in its broader mission to investigate and consider all facts and opinions that may be relevant to the resolution of an issue. One appropriate source is the information and expertise that Congress acquires in the consideration and enactment of earlier legislation. . . .

[The] petitioners' argument would force Congress to make specific factual findings with respect to each legislative action. ... I therefore conclude that [the Court] properly may examine the total contemporary record of congressional action dealing with the problems of racial discrimination against minority business enterprises.

Id. at 502-03 (Powell, J., concurring).

84 See supra note 85 and accompanying text. 


\section{A New Proposal}

A federal system serves to protect liberty by diffusing power so that overreaching by the central government is less likely and local majority control over local matters is not subordinated to one national majority ${ }^{85}$ For the federal system to perform this function, state governments must retain some measure of autonomy. Garcia requires that limits placed on the federal commerce power to ensure this autonomy be procedural in nature. ${ }^{96}$ None of the current proposals is sufficiently detailed or comprehensive to adequately protect state autonomy. ${ }^{87} \mathrm{Nev}$ ertheless, these proposals form the foundation of an effective procedural safeguard that would operate within the framework established by Garcia.

This Comment seeks to establish, consistent with the terms of Garcia, a middle ground between an unlimited commerce power and a return to National League of Cities. It is also intended that the resulting safeguard be grounded directly in the tenth amendment. ${ }^{98} \mathrm{~A}$ constitutional foundation provides the necessary basis for enforcement by judicial review. Such a foundation also avoids the logical defect inherent in self-imposed congressional rules that seek to constrain future action of the same or later Congresses. One might oppose the efforts of one Congress to constrain the actions of a future Congress on the grounds that both have equal power. ${ }^{99} \mathrm{~A}$ constitutional provision, however, is superior to legislation in that one fundamental purpose of a written Constitution is to limit the exercise of ordinary lawmaking power. ${ }^{100}$

The situations in which the proposed safeguard should operate are outlined below. The proposal itself is then elaborated, followed by a discussion of judicial enforcement. Finally, the effectiveness of this proposal as a safeguard of state autonomy is considered.

\footnotetext{
9s See supra notes 63-64 and accompanying text.

se Supra text accompanying notes 34-39.

97 See supra text accompanying notes 77-93.
}

${ }^{88}$ One reason that many proponents of federalist limitations on congressional power may hesitate to ground their proposals directly in the tenth amendment is the recognition that the thirteenth, fourteenth, and fifteenth amendments modify the tenth. This concern, however, is irrelevant in the context of the federal commerce power because congressional power exercised under those amendments simply is not a regulation of commerce.

${ }^{89}$ See, e.g., Kahn, Gramm-Rudman and the Capacity of Congress to Control the Future, 13 HASTINGS ConST. L.Q. 185, 187 (1986) (arguing that "[l]egislative power is sovereign power and as such it must be 'always free to choose between discarding and reaffirming [its] past commitments" "(citation omitted)).

100 Each legislature derives its powers from the Constitution and may exercise no more power than that instrument provides. In this fashion, the Constitution serves as a limit on the lawmaking power of the Congress. The amendment process, see U.S. Const., art V., is the only means by which a Congress can limit its successors. 


\section{A. Conditions Precedent}

This proposal operates by placing procedural requirements on congressional enactments which: (1) are based on the commerce power; (2) regulate the states; and (3) are an initial federal intrusion into an area of law. The first two requirements limit this proposal to the terms of the National League of Cities/Garcia debate. ${ }^{101}$ However, direct regulation is not required to trigger the procedural protection. The final requirement prevents the development of static classifications; unlike National League of Cities, this proposal would define protected state functions in terms of contemporary law.

Formulation of the second requirement in terms of "regulation of the states," as opposed to "direct regulation of the states,"102 is a complication necessitated by the progeny of National League of Cities. The Supreme Court upheld challenged legislation when (1) it did not regulate the states exclusively, ${ }^{103}$ or (2) states were not compelled to submit to regulation because the federal legislation offered each state the option of submitting the substantive area to complete federal preemption..$^{104}$ These two doctrines, together with the broad scope of the federal commerce power, made it unlikely that any federal legislation would be invalidated as a "direct regulation of the states." Thus, any meaningful

101 Given the historically broad interpretation of the commerce power, it may seem unusual to limit this proposal to the regulation of commerce context. Since the tenth amendment applies to the whole Constitution, this proprosal could be applied on a broader basis. Nevertheless, this Comment's proposal is put forward for only the express purpose of resolving the National League of Cities/Garcia debate, and, as such, it is limited to the commerce clause context. For a discussion of the boundaries of the National League of Cities/Garcia debate, see supra notes 26-33 and accompanying text.

102 See infra notes 103-04.

${ }^{103}$ See, e.g., Hodel v. Virginia Surface Mining \& Reclamation Ass'n, 452 U.S. $264,283-93$ (1981). Although the act challenged in this case was addressed to "private persons and businesses," to the extent that the states did not want to abrograte regulation of the area entirely, its practical effect was to require states to adopt mandatory minimum federal standards. Stressing that Congress has the authority to preempt state laws regulating private activity affecting interstate commence, the Supreme Court held that the act did not regulate the "States as States." Id. at 293. The Court's formalistic practice of examining legislation only in terms of the party to which it was addressed, see id. at 288, and ignoring its likely effect on the states, creates the potential for circumvention: if direct regulation of the states could be artfully phrased so as to appear to be regulation of private parties, tenth amendment limitations would not apply.

${ }_{104}$ See, e.g., FERC v. Mississippi, 456 U.S. 742, 764 (1982) ("[T]he Federal Government could have pre-empted all [of the state regulations]; instead it allowed the States to enter the field if they promulgated regulations consistent with federal standards. ... . [T] his raised no Tenth Amendment problem"); Hodel, 452 U.S. at 288, 290 ("TT]here can be no suggestion that the Act commandeers the legislative processes of the States by directly compelling them to enact and enforce a regulatory program. . . Congress chose to allow the States a regulatory role." (citations omitted)). 
protection of state autonomy must reformulate the "regulation of the states" inquiry to avoid these limitations. ${ }^{105}$ Deletion of the term "direct," however, is not designed to bring all federal legislation within the scope of this proposal. Legislation that regulates only private parties would still be exempted.

The third requirement's focus on initial intrusions further narrows the impact and scope of the proposed safeguard. The "initial intrusions" limitation respects the historical development of federalism; it has prospective application only, and past expansion of national power at the expense of state autonomy would be unaffected. Additionally, the "initial intrusions" limit does not create a static standard. When, pursuant to these procedural requirements, federal legislation has established a new equilibrium, this would be acknowledged and future actions of Congress need not comply with the safeguards. That is, if Congress continued to expand into areas governed by state law with a series of statutes expressly identifying the state laws displaced or the burdens imposed on state interests, once the field became governed by federal law, additional federal statutes in the area would not need to address the states' interests in regaining control of that area. Because this line can shift over time and is not rigid, its parameters may be less clearly defined.

This approach overcomes one of the primary defects of National League of Cities: it obviates the need to forever classify subjects as. falling on one side of the line or the other, because there is an implicit acknowledgement of a grey area between powers defined as "federal" or "state" at any given time. When federal legislation transcends the boundary of clearly defined federal powers and enters either the grey area or an area of state control, compliance is mandated; the federal government, however, has the power to gradually redefine these areas, and they may expand or contract over time. ${ }^{106}$

105 Indeed, it is possible to go much further. Federal regulation of private parties that affects existing state regulation of those parties could be subject to limitation. Such a restriction of federal power would be beyond the scope of the National League of Cities / Garcia debate. At the cost of mandating a major restructuring of current constitutional law, the broader proposal would offer a far simpler test: a factual inquiry as to whether an area is currently governed, at least in part, by nonfederal law would replace the need to determine whether federal legislation "regulates the states."

${ }_{106}$ Limiting the procedural requirements to "initial intrusions" and allowing the area of federal law to expand over time more than compensates for the broadening of protection to instances where legislation merely "regulates the states."

Federal retreat from an area will further complicate the analysis. See Baird, supra note 24, at 517 ("As the national government chooses to deregulate fields it has been in, the states will confront questions of whether they can now regulate or whether Congress intended to leave the field unregulated.") (citing Arkansas Elec. Coop. v. Arkansas Pub. Serv. Comm'n, 461 U.S. 375, 383-84 (1983)). 


\section{B. The Proposed Safeguard}

Federal legislation satisfying these conditions would be required to comply with certain procedural safeguards. Simply stated, the safeguard herein proposed requires: (1) explicit statements on the face of federal statutes expressing the degree to which state law will be affected by the legislation; (2) specific findings and examples of state laws affected; and (3) that these procedures be followed by Congress and not delegated to administrative agencies. ${ }^{107}$ Grounding these requirements directly in the tenth amendment ${ }^{108}$ assures that they will be accorded constitutional status. The requirement of explicit statements on the face of a statute serves to increase the likelihood of actual notice to the states and simplifies judicial inquiry in the face of legislative silence.

The requirement that Congress make specific findings and cite examples of state laws which would be affected by proposed legislation guarantees that a simple pro forma statement that Congress intends to preempt all contrary state law would be insufficient to satisfy the explicit statement requirement. Instead Congress would have the burden of surveying the state law already in place and determining which laws it intends to displace. This recognizes that legislation is likely to have many facets, and that state interests in retaining control over matters tangential to the primary thrust of a particular congressional proposal are not likely to be considered unless an explicit statement of the legislation's impact on these interests is required.

The specific findings made by Congress should include a description of: (1) the direct impact of the proposed legislation; (2) the current division of authority between national and state governments in the area to be regulated by the proposed legislation; (3) the identity and degree of impact of the proposed legislation on existing state law, including an analysis of alternative measures; and (4) the long-term structural effects of intrusion, contrasted with short-term policy gains.

When defining the scope of the impact of proposed legislation, Congress should cite specific state laws and practices that would be

107 Compare parts (1) and (2) of this proposal with Justice Stevens' example of the proper functioning of Congress when legislating in areas of process concern. See supra text accompanying note 74 .

${ }_{108}$ See supra notes $98-100$ and accompanying text. However, by asserting a firm foundation in the tenth amendment, the door is opened to the claim that subsequent constitutional amendments may be interpreted as modifiying the boundaries, just as the fourteenth amendment has been interpreted as creating an exception to the eleventh amendment. See infra text accompanying notes 141-47. This concern is misplaced in the context of the power to regulate commerce. See supra note 98. Furthermore, current eleventh amendment doctrine parallels these proposed safeguards. See infra text accompanying notes $141-47$. 
affected. Citation to state laws that would remain unaffected would produce a more precise definition of the scope of the congressional action. Preparation of the congressional findings will, in most cases, require research and public hearings. At this stage, meaningful debate on alternatives and long-term structural effects is still possible.

The requirement that Congress itself act rather than empowering administrative agencies with the discretion to displace state law is necessary to prevent circumvention of the express statement and specific findings requirements. This element also serves to ensure that Congress remains accountable, because primary reliance on political safeguards necessitates action by a political branch of government.

\section{Judicial Enforcement}

Congressional compliance with these procedural requirements would be enforced by the judiciary. Two approaches would be employed: statutory construction and judicial review. First, courts would construe federal legislation narrowly. Where the congressional findings did not affirmatively demonstrate an intent to displace related state law, the state law would stand. Thus, when Congress legislated broadly, two issues would arise: (1) whether the findings indicate an anticipation of impact on this particular facet of the broad area, and (2) if Congress intended to have an impact on this facet, whether the particular state law or interest conforms to one of the specific examples cited in the findings. When the answer to either of these inquiries was in the negative, the federal law would be construed as effectively allowing an exemption for the conflicting state law.

Congressional action that did not comply with these procedural requirements could also be held unconstitutional and denied effect. However, the courts would invalidate only the method of enactment and not the substantive legislative judgement. Essentially, the courts would find "procedural due process" limits on congressional power. This would allow subsequent enactment of the same legislative scheme to be upheld, provided the re-enactment complied with the procedural requirements.

\section{Impact of the Proposed Safeguard}

If this proposal is to be embraced, it must limit the federal government's ability to intrude arbitrarily upon state interests, but allow an intrusion if Congress deems it truly necessary. Recent scholarship asserts that procedural safeguards, judicially enforced, can serve this dual function. 
In practical terms, requiring Congress to address an issue, such as the impact of legislation upon federalism, adds to the cost of passing that legislation. That is, "the establishment of any rule [of construction] reduces the power of Congress by forcing it to enact around the rule if dissatisfied. Because displacing any rule . . . is costly, . . . Congress is not always willing or able to bear these costs."100 To use Professor Macey's terminology, the cost of enacting "hidden-implicit" statutes is increased. ${ }^{110}$ By making enactment of these statutes that hide the purpose and cost of the legislation more difficult, "open-explicit" statutes will be substituted. ${ }^{111}$ However, open-explicit statutes are more costly, ${ }^{112}$ and thus fewer will be enacted. ${ }^{113}$ Many of the special interest groups that support hidden-implict deals will instead abandon the legislative process. ${ }^{114}$ In the "interest group model of legislation," the result of imposing rules of statutory construction and procedural safeguards is a significant transformation of the legislative process; "legislators who really believe they are acting in the public interest" are provided "useful information as to the true consequences of their actions," circumventing their usual reliance on information supplied by special interests. ${ }^{115}$

The judiciary has cited "process concerns," that is, the fear of overwhelming courts with cases, as a reason to defer to congressional definition of the scope of federalism. ${ }^{116}$ However, as Professor Zacharias observes, process concerns must be considered together with the potential "political effects" of judicial actions. ${ }^{117}$ This political effects model recognizes that the legislature will respond to certain judgemade rules. ${ }^{118}$ In effect, the courts transform the normal legislative process by placing a burden or liability on a politically powerful interest with the expectation that the interest group will initiate public debate and a search for acceptable compromises. ${ }^{119}$ Similarly, the procedural

109 Easterbrook, Statutes' Domains, 50 U. CHI. L. Rev. 533, 539 (1983).

110 See Macey, Promoting Public-Regarding Legislation Through Statutory Interpretation: An Interest Group Model, 86 Colum. L. Rev. 223, 232-33, 236 (1986) ("Open-explicit statutes are naked, undisguised wealth transfers to a particular, favored group. By contrast, hidden-implicit statutes are couched in public interest terms to avoid the political fallout associated with blatant special interest statutes.").

111 See id. at 238 \& n.73.

112 See id. at 233.

113 See id. at 238 n.74.

114 See id.

115 Id. at 231 \& n.42.

116 See supra text accompanying notes 46-52.

117 See Zacharias, The Politics of Torts, 95 Yale L.J. 698, 714 (1986).

118 See id. at 698, 714-15.

110 See id. at 715-25 (citing as examples of this process railroad injuries and workmen's compensation, medical malpractice, and environmental litigation). 
safeguard proposed herein would transform the legislative process by forcing Congress to expressly define the extent to which it intends to encroach upon state autonomy.

The proposed safeguard is merely an elaboration of the long-accepted doctrine of "legislative remand," where the judiciary " "refrain[s] from passing upon the constitutionality of an act of Congress unless obligated to do so." "120 " "TT]he judge, conscious of the fallibility of the human judgment, will shrink from exercising [this power] in any case where he can conscientiously and with due regard to duty and official oath decline the responsibility." "121 To avoid constitutional questions, the Court has developed many techniques: ${ }^{122}$

The Court will not "anticipate a question of constitutional law in advance of the necessity of deciding it." . . .

. . . The Court will not "formulate a rule of constitutional law broader than is required by the precise facts to which it is to be applied."

... The Court will not pass upon a constitutional question although properly presented by the record, if there is also present some other ground upon which the case may be disposed of. ...

. . "When the validity of an act of the Congress is drawn in question, and even if a serious doubt of constitutionality is raised, it is a cardinal principle that this Court will first ascertain whether a construction of the statute is fairly possible by which the question may be avoided."123

The result of judicial action which avoids a problematic construction of a statute or which merely invalidates on a procedural basis is a "remand" to the legislature. Congress is afforded an opportunity to clarify the scope of the challenged legislation in light of the Supreme Court's action. Rather than stating that Congress may not enact certain legislation, the Court signifies that there is a problem and that it is unsure whether Congress ever considered its action within the context

120 Ashwander v. TVA, 297 U.S. 288, 341 (1935) (quoting Blair v. United States, 250 U.S. 273, 279 (1919) (Brandeis, J., concurring)).

121 Id. at 345 (quoting 1 I. Cooley, Constitutional Limitations 332 (8th ed. 1927)).

122 See id. at 345-48. In addition to the numerous judicial doctrines, Justice Brandeis cites the constitutional requirement that the judiciary address only actual cases or controversies, and not render advisory opinions. See id. at 345-46.

${ }^{128} \mathrm{Id}$. at 346-48 (citations omitted). 
of this problem. ${ }^{124}$

A second major effect of establishing rules of construction is that default rules may significantly lower the costs of legislation. ${ }^{125}$ Efficiency is served by eliminating the need for Congress to consider all contingencies in the course of framing legislation. ${ }^{126}$ Hence, where Congress does not intend its legislation to have an impact on state laws, no effort need be made to ensure this result, because the courts would construe the absence of explicit statements as manifesting an intent not to displace the states' interests.

It is important that congressional silence be construed as intent not to affect state laws. Such a system ensures fair notice to states when legislation affecting their interests is proposed. ${ }^{127}$ Congress still has the power under the supremacy clause ${ }^{128}$ to pass preemptive legislation, but the political process, as Garcia teaches, is responsible for defending states' interests openly. When a clear statement is required, states have the opportunity to oppose undesirable legislation before it becomes law. Under the congressional committee model discussed above, Congress will focus on the impact of proposed legislation on the states. ${ }^{129}$ How-

124 Cf. Kent v. Dulles, 357 U.S. 116, $127-30$ (1958) (stating that the right of exit is a liberty interest and therefore, although legislation giving the Secretary of State "generalized power and authority" to deny the issuance of a passport to certain citizens will not be stricken as unconstitutional, the Secretary's exercise of this power will not be given effect when used "to trenchl] heavily on the rights of citizens.").

${ }^{225}$ See Easterbrook, supra note 109, at 540 ("[S]ome rules of statutory construction are useful for the same reason rules are useful in interpreting contracts. They spare legislators the need to decide, and announce law by law, the rules that will be used for interpreting the code of words they select. [This results in a] general reduction in the costs of legislating.").

${ }^{128}$ See id.

127 Due process rights of notice and opportunity to be heard are usually confined to adjudicatory functions of government. Legislative functions, on the other hand, operate on a theory of representation, in that members of the legislature are expected to defend the interests of those constituents who are affected. See, e.g., Bi-Metallic Inv. Co. v. State Bd. of Equalization, 239 U.S. 441, 445 (1915) ("The Constitution does not require all public acts to be done in town meeting or an assembly of the whole. ... [S]tatutes . . . are passed that affect the person or property of individuals, sometimes to the point of ruin, without giving them a chance to be heard. Their rights are protected in the only way they can in a complex society, by their power, immediate or remote, over those who make the rules."). However, to the extent that this proposal undermines this distinction, the same criticism applies whenever Congress is required to conduct hearings or make specific findings. This is what is currently demanded of Congress for legislation that is subject to strict scrutiny under the equal protection clause and for regulation of intrastate commerce under the "affecting commerce" doctrine.

${ }^{228}$ U.S. CoNST. art. VI, cl. 2 ("This Constitution, and the Laws of the United States which shall be made in Pursuance thereof; and all Treaties made, or which shall be made, under the Authority of the United States, shall be the supreme Law of the Land; and the Judges in every State shall be bound thereby, any Thing in the Constitution or Laws of any State to the Contrary notwithstanding.").

229 See Baird, supra note 24 , at $514-15$. 
ever, this Comment's proposal goes further by allowing the states to represent their own intersts rather than trusting Congress to police itself.

Glear statement requirements force Congress to confront the reality of what it is doing. "[U]nless Congress conveys its purpose clearly, it will not be deemed to have significantly changed the federal-state balance. . . . [T] he requirement of clear statement assures that the legislature has in fact faced, and intended to bring into issue, the critical matters involved in the judicial decision."130

This Comment's proposal would similarly transform the legislative process. Public debate would be generated, in a manner effectively reshaping the actions of interest groups.

\section{SUPPORT FOR THIS PROPOSAL}

Clear statement rules of statutory construction are used frequently in contemporary jurisprudence. Express statements are required in the area of environmental regulation, ${ }^{131}$ in defining the scope of federal criminal statutes, ${ }^{192}$ and in the area of labor antitrust issues. ${ }^{133}$

Current eleventh amendment ${ }^{134}$ doctrine is also based on clear statement principles. In Atascadero State Hospital v. Scanlon, ${ }^{135}$ decided just four months after Garcia, ${ }^{138}$ the Supreme Court imposed procedural requirements on federal legislation. The Court stated that "the Eleventh Amendment is 'necessarily limited by the enforcement provisions of $\S 5$ of the Fourteenth Amendment," "137 such that "when

130 Id. at 501 (quoting United States v. Bass, 404 U.S. 336, 349 (1971)).

131 See id. at 501 \& n.49 (citing Brown v. EPA, 521 F.2d 827, 834 (9th Cir. 1975), vacated and remanded on other grounds, 431 U.S. 99 (1977); Brown v. EPA, 566 F.2d 665, 669 (9th Cir. 1977) (prohibiting the EPA from imposing sanctions on a state or its officials for pollution-creating activities)).

132 See id. at 501 \& n.47 (citing United States v. Bass, 404 U.S. at 349-50 (1971) (narrowing the scope of a federal criminal statute outlawing behavior already proscribed by the states)).

1ss See id. at 501 \& n.48 (citing Apex Hosiery Co. v. Leader, 310 U.S. 469, 513 (1940) (limiting the application of federal antitrust laws to local labor disputes)).

1se "The Judicial power of the United States shall not be construed to extend to any suit in law or equity, commenced or prosecuted against one of the United States by Citizens of another State, or by Citizens or Subjects of any Foreign State." U.S. CoNsT. amend. XI.

185473 U.S. 234 (1985).

136 Garcia, 469 U.S. 528 (1985), was decided on February 19, 1985. Atascadero, 473 U.S. 234, was decided on June 28, 1985.

137 Atascadero, 473 U.S. at 238 (quoting Fitzpatrick v. Bitzer, 427 U.S. 445,456 (1976)). Section 5 of the fourteenth amendment grants Congress the power "to enforce by appropriate legislation" the substantive provisions of the fourteenth amendment. U.S. ConsT. amend. XIV, $\S 5$. The substantive provisions include the due process, privileges and immunities, and equal protection clauses. Id. at $\S 1$. 
acting pursuant to $\S 5$ of the Fourteenth Amendment, Congress can abrogate the Eleventh Amendment without the States' consent." ${ }^{\text {'38 }}$ However, since "the Eleventh Amendment implicates the fundamental constitutional balance between the Federal government and the States,"139 the Supreme Court requires " an unequivocal expression of congressional intent to [use this power and] "overturn the constitutionally guaranteed immunity of the several States."'\$140

This Comment's proposal parallels the requirements of eleventh amendment protection stated in Atascadero. The Court rejected "preand post-enactment legislative history of the [law in question] and inferences from general statutory language"141 and declared that Congress can limit the states' interests "only by making its intention unmistakably clear in the language of the statute."142 For Congress to expand federal power at the expense of the states, it must unequivocally express this intent on the face of the statute. ${ }^{143}$ Thus, Atascadero held that a general statutory provision which applied to "any recipient of Federal assistance"144 did not explicitly subject states to suit in federal court. Subsequent to Atascadero, Congress amended this statute evidence that "legislative remand" works. The amendment followed the clear statement requirement established by the Court. It stated unambiguously: "A State shall not be immune under the Eleventh Amendment of the Constitution of the United States from suit in Federal court for a violation of section 504 of the Rehabilitation Act of $1973 \ldots$. . 145

Similarly, Employees v. Missouri Department of Public Health and Welfare ${ }^{146}$ concluded that without an explicit statement of congresional intent the FLSA would not be construed to authorize suits against states by their employees in federal court. ${ }^{147}$ This case, however, did not rely explicitly on the eleventh amendment. ${ }^{148}$ Other recent

${ }^{138}$ Atascadero, 473 U.S. at 238.

139 Id. The Court states "that our Eleventh Amendment doctrine is necessary to support the view of the federal system held by the Framers of the Constitution. The Framers believed that the States played a vital role in our system and that strong state governments were essential to serve as a 'counterpoise' to the power of the federal government." Id. at 239 n.2 (citations omitted).

${ }^{140} I d$. at 240 (quoting Pennhurst State School and Hosp. v. Halderman, 465 U.S.

89, 99 (1984), (quoting Quern v. Jordan, 440 U.S. 332, 342 (1979))).

141 Atascadero, 473 U.S. at 242.

142 Id. (emphasis added).

143 See id. at 243 (requiring "unmistakable language in the statute itself").

144 Id. at 245.

145 Rehabilitation Act Amendments of 1986, Pub. L. No. 99-506, § 1003, 1986

U.S. Code Cong. \& Admin. News (100 Stat.) 1845.

146411 U.S. 279 (1973).

167 See id. at 285-86; Baird, supra note 24, at 499.

148 See Missouri Pub. Health Dep't., 411 U.S. 279; Baird, supra note 24, at 499. 
cases have also adopted the clear statement requirement without invoking the eleventh amendment. ${ }^{148}$

Conditions on federal funding are also subject to clear statement requirements in areas where states' interests may be undermined. Under current doctrine, "the federal government may impose express conditions on state use of federal monies without judicial review of the extent to which these conditions enhance the scope of the federal government's authority, so long as the states are able to reject the aid and thereby the conditions." ${ }^{\text {"130 }}$ This was an issue in Atascadero as well. ${ }^{151}$ There the Court concluded that in addition to not overriding the eleventh amendment interests of the states,

The [Rehabilitation] Act likewise falls far short of manifesting a clear intent to condition participation in the programs funded under the Act on a State's consent to waive its constitutional immunity. Thus, were we to view this statute as an enactment pursuant to the Spending Clause we would hold that there was no indication that the State ... consented to federal jurisdiction. ${ }^{152}$

Under current preemption doctrine as well, the Court requires " $a$ clear congressional statement"16s before presuming Congress "intended to preempt a field traditionally regulated by the states."154 This doctrine requires, like the proposed safeguard, that intent to preempt be

149 See, e.g., Arizona Governing Comm. v. Norris, 463 U.S. 1073 (1983); Los Angeles Dep't. of Water and Power v. Manhart 435 U.S. 702 (1978); Baird, supra note 24 , at 499 .

${ }_{180}$ Baird, supra note 24, at 511 n.93 (citing Pennhurst State School \& Hosp. v. Halderman, 451 U.S. 1, 17 (1981)) (emphasis added). Even allowing for the rejection of conditions, some hypothetical requirements are so destructive of the Constitution as to imply substantive limitations on this power. See Van Alstyne, supra note 14, at 1714 n.25. Van Alstyne argues that:

the doctrine of unconstitutional conditions presumably will apply to forestall a complete end run around . . . federalism, despite the conventional wisdom of the spending power. It is doubtful, for instance, that Congress could condition receipt of federal funds for state revenue-sharing by restricting eligibility to those states whose legislatures would ratify a proposed constitutional amendment [or] a limitation on revenue-sharing confined to states that altered their laws to permit eighteen-year-olds to vote, or . . . undertook to move the state capitol to a location that, in the view of Congress, was more consistent with "the general welfare."

Id.

161 Atascadero, 437 U.S. 234, 244 n.4 (1985) ("Petitioners assert that the Rehabilitation Act of 1973 does not represent an exercise of Congress' Fourteenth Amendment authority, but was enacted pursuant to the Spending Clause.").

162 Id. at 247 (citation omitted).

153 Baird, supra note 24 , at 500 (emphasis added).

164 Id. 
clear and stated by Congress itself. The result is that federal legislation is narrowly construed. For instance, Pacific Gas \& Electric Co. v. State Energy Resources Conservation and Development Commission ${ }^{155}$ held that the Atomic Energy Act, ${ }^{18 B}$ a federal law governing the safety aspects of nuclear power plants, preempted only state regulation over the safety of such plants, ${ }^{\mathbf{1 5 7}}$ and thus state laws premised on states' "traditional authority" over issues such as licensing, ratemaking, and capacity were valid. ${ }^{168}$

Nevertheless, implementation of the proposed safeguard would require a fundamental realignment of traditional preemption doctrine, at least within the parameters defined as conditions precedent. ${ }^{159}$ The traditional preemption standards are summarized by the Supreme Court:

It is well established that within constitutional limits Congress may pre-empt state authority by so stating in express terms. Absent explicit pre-emptive language, Congress' intent to supersede state law altogether may be found from a " scheme of federal regulation . . . so pervasive as to make reasonable the inference that Congress left no room for the States to supplement it,' because 'the Act of Congress may touch a field in which the federal interest is so dominant that the federal system will be assumed to preclude enforcement of state laws on the same subject,' or because 'the object sought to be obtained by the federal law and the character of obligations imposed by it may reveal the same purpose." " Even where Congress has not entirely displaced state regulation in a specific area, state law is pre-empted to the extent that it actually conflicts with federal law. Such a conflict arises when "compliance with both federal and state regulations is a physical impossibility," or where state law "stands as an obstacle to the accomplishment and execution of the full purpose and objectives of Congress."160

Some of these standards would remain intact under the proposed

185461 U.S. 190 (1983).

158 Atomic Energy Act of 1954, Pub. L. No. 83-703, 68 Stat. 919 (codified as amended at 42 U.S.C. $\S \S 2011-2296$ (1982 \& Supp. III 1985 \& West Supp. 1987)).

${ }^{157}$ Pacific Gas, 461 U.S. at 211-13.

188 Id. at 212.

159 That is, where congressional enactments are founded on the commerce power, regulate the states, and are an initial federal intrusion into an area of law. See supra text accompanying notes 101-106.

${ }_{160}$ Pacific Gas, 461 U.S. at 203-04 (citations omitted). 
procedural safeguard. For example, preemption by express Congressional statement would remain possible, although such statements would be required to be contained on the face of the statute. Preemption through a pervasive scheme of federal regulation would remain unchanged. ${ }^{161}$ Where Congress chooses to preempt state law solely by implication, however, the proposed safeguard would require significant modification in current preemption doctrine. Specifically, preemption due to the similarity of purpose of state and federal legislation, preemption due to an actual conflict between the laws, and preemption because state law forms an obstacle to the objectives of federal legislation would be severely limited.

While the supremacy clause ${ }^{162}$ guarantees that "the Laws of the United States which shall be made in Pursuance [of the Constitution] . . . shall be the supreme Law of the Land," "16s the Supreme Court has clearly held that not every congressional enactment is a law in pursuance of the Constitution. ${ }^{164}$ Grounding the proposed procedural requirements in the tenth amendment elevates them to a constitutional level, thus limiting the practice of congressional preemption of state law by implication. The requirement that specific findings be conducted to supply specific examples of state laws that would be affected by proposed legislation would force Congress to make these implicit results explicit.

It is in the area of preemption that federalism may be most easily observed as the basis for an independent rule of statutory construction, rather than as simply a manifestation of the general rule that statutes should be construed to be constitutional where the language so permits. In instances where several interpretations would be constitutional, state-protective constructions are still generally preferred. Thus,

Throughout federal law we see the courts invoking a principle of "clear statement" as a way of interpreting statutes affecting the federal-state balance. Because of a background commitment to federalism values, the courts will not lightly conclude that Congress has meant to intrude on the states;

101 Allowing for change in the federal-state equilibrium to exempt Congress from the need to continue to satisfy the proposed procedural requirements is an integral part of this proposal. Thus, once state law is displaced pursuant to these safeguards, that area of law is deemed federal and no further compliance with the procedure is required.

168 U.S. ConST, art. VI, cl. 2.

168 Id.

104 See, e.g., Marbury v. Madison, 5 U.S. (1 Granch) 137, 176-79 (1803) (statute contradicting the Constitution or not duly authorized by it is not a law); supra notes $24,38$. 
rather, the courts insist that Congress clearly state its intention to do so. Thus, a distinctive burden is placed on Congress expressly to authorize actions affecting the federal state balance. $^{185}$

The use of clear statement requirements in these areas of federalism conflicts reveals the possibility that the Supreme Court is already gradually developing such a test for use in commerce clause/tenth amendment conflicts. Recently the Court took the first step toward the framing of a clear statement requirement. The Court's action, however, can only be described as a haphazard groping and not a formal announcement of a standard.

Last Term in Bowen v. American Hospital Association, ${ }^{166}$ a plurality of the Court employed an unusual analysis to determine the validity of administrative rules promulgated under to the Rehabilitation Act. ${ }^{167}$ First, the Court determined that the rules represented the initial intrusion of federal law into an area primarily governed by state law: "Prior to the regulatory activity culminating in the Final Rules [which are here challenged], the federal Government was not a participant in the process of making treatment decisions for newborn infants."168 Then the Court examined the Department of Health and Human Services' justifications for the regulations and concluded that they were based on the "manifestly incorrect perception that withholding of treatment in accordance with parental instructions necessitates federal regulation."169 It appeared to the Court that the Department "repeatedly makes the assumption that evidence showing the need for governmental involvement provides a basis for federal involvement."170 Thus, no real consideration was given to the record of state involvement prior to the determination that federal intervention was necessary.

Rather than directly regulating hospitals and requiring that they report compliance to the federal government, "the Final Rules command state agencies to require such reports, regardless of the state agencies' own reporting requirements."171 Furthermore, "the Final Rules command state agencies to utilize their 'full authority' to 'prevent

${ }^{165}$ Baird, supra note 24 , at 500-01 (footnote omitted).

188106 S. Ct. 2101 (1986).

${ }^{167}$ Rehabilitation Act of 1973, $\S 504,29$ U.S.C. $\S 794$ (1982 \& West Supp. 1987). It must be noted, however, that the standard of review for administrative actions is less deferential than that for congressional enactments.

168 Bowen, 106 S. Ct. at 2113.

189 Id. at 2118.

${ }^{170}$ Id. at 2117 n.21.

171 Id. at 2119. 
instances of unlawful medical neglect of handicapped infants." "172 In response, the Court declared: "To say that the Secretary can give detailed marching orders to state agencies upon discovering that both the agencies and HHS are working toward the same general objective-at least when defined with sufficient abstractness-would countenance a novel and serious intrusion on state autonomy."173

Bowen announced that "[s]tate child protective services agencies are not field offices of the HHS bureaucracy, and they may not be conscripted against their will as the foot soldiers in a federal crusade"174 because "[i]mportant principles of federalism are implicated by any 'federal program that compels state agencies ... to function as bureaucratic puppets of the Federal Government." "178 What is most unusual is that the majority here cited Justice O'Connor's partial dissent in FERC v. Mississippi ${ }^{176}$ to support this proposition. FERC applied the National League of Cities test and sustained federal legislation that required state agencies to "consider" federally proposed standards using federally prescribed notice and comment procedures, and to give reasons for their decisons on the proposed standards. ${ }^{177}$ Justice O'Connor argued, however, that such a result was incompatible with the National League of Cities test. ${ }^{178}$

Having overruled National League of Cities in Garcia, it is unusual and significant that the Court has now adopted Justice O'Connor's reasoning in FERC. The majority's choice of support becomes even more confusing because the citation fails to acknowledge clearly that Justice O'Connor criticized the 'majority's holding in FERC. ${ }^{178}$

Finally, in Bowen the Court observed that " [w]e must assume that the implications and limitations of our federal system constitute a major premise of all congressional legislation" "180 and thus " '[u]nless

172 Id. at 2119 (citations omitted).

173 Id. at 2119 n.26.

174 Id. at 2120.

178 Id. at 2120 n.29 (citing FERC v. Mississippi, 456 U.S. 742, 783 (1982) (opinion of O'Connor, J., concurring in part and dissenting in part)).

178 456 U.S. at 775 . Although Justice O'Connor concurred in part with the judgment of the Court in FERC, she disagreed with the Court's tenth amendment analysis, concluding that "a proper 'sensitivity to the legitimate interests of both State and National Governments' requires invalidation of [several of the provisions in question] insofar as they apply to state regulatory authorities." Id. at 797 (citation omitted).

177 Id. at 758-71.

${ }^{178}$ See id. at 778-79.

170 As it appears in Bowen, $106 \mathrm{~S}$. Ct. at $2120 \mathrm{n.29}$, the citation is "FERC v. Mississippi, 456 U.S. 742, 783 . . . (1982) (opinion of O'Connor, J.)."

${ }_{180}$ Bowen, 106 S. Ct. at 2121 (quoting United States v. Five Gambling Devices, 346 U.S. 441,450 (1953) (plurality opinion)). 
Congress conveys its purpose clearly, it will not be deemed to have significantly changed the Federal-State balance." "181 "'[W] henever the federal power is exerted within what would otherwise be the domain of state power, the justification of the exercise of the federal power must clearly appear.' That is 'it must appear that there are findings, supported by evidence, of the esential facts . . . which would justify [the Secretary's] conclusion." "182 This language suggests that requirements very similar to the proposed procedural safeguards are already being employed.

Because the Supreme Court has adopted clear statement requirements in other federalism contexts and has stated this requirement while relying on Justice O'Connor's opinion in FERC, which dealt with the commerce clause/tenth amendment boundary, an express shift to such a requirement in this area would not necessarily be disruptive. In fact, transition could be achieved in a prospective-only fashion by reinterpreting Bowen or a similar case as having already placed Congress on notice. This would minimize displacement of legislation. The only major change required is a limitation of traditional preemption doctrine within the narrow scope of commerce-power based regulation of the states.

\section{Conclusion}

Our federal system envisions autonomous states as a bulwark of individual liberty. To serve this function states must be protected from unlimited regulation by the federal government under the commerce clause. The immediate benefits from federal legislation must be measured against the long-term structural effects of greater concentration of power at the national level.

In theory, no procedural protection can absolutely protect state autonomy from congressional encroachment. However, as long as functions entitled to substantive protection remain undefined, procedural limitations help to restrain congressional intrusions on state autonomy. Procedural requirements that demand express statements of the impact of legislation add to the political cost of the legislation and thus serve to limit Congress's exercise of its commerce power. This restraint, in turn, acts to filter the instances where states may call on substantive protection. In effect, the judiciary ensures that only the most compelling cases for the limitation of congressional authority will be heard on the merits.

181 Id. at 2121 n.33 (quoting Heublein, Inc. v. South Carolina Tax Comm'n, 409 U.S. $275,281-82(1972))$.

${ }^{182}$ Id. at 2122 (citations omitted). 
As a minimum level of protection of state interests, Congress should be forced to confront the impact of its legislation on the states. Express consideration of how a given measure would affect the situation in a specific state would also increase the ability of that state to present evidence at hearings, recommend less intrusive alternatives, and oppose legislation. As a rule of statutory construction, a clear statement requirement guarantees that federal legislation, in areas of state sovereignty, is not expanded beyond the scope intended by Congress. Nevertheless, procedural requirements preserve Congress's power to invade and preempt an area currently governed by state law even when this would limit state autonomy. Congress also retains the ability to experiment with solutions without forever altering the balance of federalism. 